\title{
What makes a Right a Human Right? The Philosophy of Human Rights
}

\section{Christian Erk}

Undoubtedly, the idea of rights and especially human rights is pervasive these days. According to some, the discourse of human rights has acquired 'in recent times [...] the status of an ethical lingua franca' ; others hold that 'there are few mechanisms available other than human rights to function as a global ethical foundation' 2 , consider it the 'dominant morality of our time, [...] a truly global morality' 3 or even call it 'the world's first universal ideology'4. The worldwide acceptance of the idea of human rights is also reflected by the fact that all of the almost 200 states in the world have acknowledged the existence of human rights - either in their constitutions and/or by means of ratification of one or more of the relevant treaties, declarations or covenants of international law. Today, hardly any state would dare - at least not publicly - to question the very idea of human rights. Consequently, there is scarcely any statement with regard to social and political life that is not affirmed using the term rights: 'these days it is usually not long before a problem is expressed as a human rights issue'5. To cut a long story short: we live in an age of (human) rights.

But the mere existence and continuous ratification of international human rights instruments does not allow for the conclusion that there is a universal concept of human rights. Upon closer look, a regrettable lack of theory becomes obvious. Although the idea of universal human rights is being increasingly accepted, explicated and refined in the realm of international law, there is no universally shared theoretical foundation of such rights: 'the morality of human rights is not well understood' 6 . While it is undoubtedly true that there is something deeply attractive about the idea of human rights, attractiveness alone cannot be a sustainable foundation for the ever-growing catalogue of alleged human rights. If one looks at the foundation of the concept of human rights, one soon has to realise that - as Griffin puts it - the term human right has become 'seri-

1 John Tasioulas, 'The Moral Reality of Human Rights' in Thomas Pogge (ed), Freedom from Poverty as a Human Right: Who Owes What to the Very Poor? (OUP, Oxford 2007) 75.

2 David C. Thomasma, 'Evolving Bioethics and International Human Rights' in David D. Weisstub, Guillermo Díaz Pintos (eds), Autonomy and Human Rights in Health Care. An International Perspective (Springer, Dordrecht 2008) 13.

3 Michael J. Perry, Toward a Theory of Human Rights: Religion, Law, Courts (CUP, Cambridge 2007) 4.

4 David Weissbrodt, 'Human rights: a historical perspective' in Peter Davies (ed), Human Rights (Routledge, London \& New York 1988) 1. Also cf. Manfred Nowak, Einführung in das Menschenrechtssystem (Neuer Wissenschaftlicher Verlag, Wien und Graz 2002) 13.

5 Andrew Clapham, Human Rights: A Very Short Introduction (OUP, Oxford 2007) 1.

6 Perry (n 3) 4. 
ously debased'7 and that 'there are few criteria for determining when the term is used correctly and when incorrectly'8.

The reason for this grievance is the fact that human rights are "the rights of lawyers, not the rights of philosophers'9. Hence, it is not surprising that the major human rights documents signed by the international community during the past fifty years do not address underlying philosophical issues and are not concerned with identifying the normative foundation of human rights. In fact, 'there is very little moral philosophy written into the documents that constitute the framework for the United Nations human rights regime' 10 . In consequence of this unfortunate lack the realm of human rights seems to be rather theory-free. That this description is not a cynical phantasm, but indeed a true description of reality, can be gathered from the experiences of Jacques Maritain, a French theologian and philosopher who headed the French delegation at the UNESCO meetings in Mexico City during November and December 1947:

During one of the meetings of the French National Commission of UNESCO at which the Rights of Man were being discussed, someone was astonished that certain proponents of violently opposed ideologies had agreed on the draft of a list of rights. Yes, they replied, we agree on these rights, providing we are not asked why. With the 'why', the dispute begins. The subject of the Rights of Man provides us with an eminent example of the situation that I tried to describe in an address to the second international conference of UNESCO ${ }^{11}$, from which I take the liberty of quoting a few passages. 'How,' I asked, 'is an agreement conceivable among men assembled for the purpose of jointly accomplishing a task dealing with the future of the mind, who come from the four corners of the earth and who belong not only to different cultures and civilizations, but to different spiritual families and opposing schools of thought? Since the aim of the UNESCO is a practical aim, agreement among its members can be spontaneously achieved by virtue not of common speculative notions, but of common practical no-

7 James Griffin, 'First Steps in an Account of Human Rights' (2001) 9 European Journal of Philosophy $306,306$.

8 James Griffin, On Human Rights (OUP, Oxford 2008) 14. Also cf. Griffin (n 8) 2: 'When during the seventeenth and eighteenth centuries the theological content of the idea was abandoned, nothing was put in its place. The term was left with so few criteria for determining when it is used correctly, and when incorrectly, that we often have only a tenuous, and sometimes plainly inadequate, grasp on what is at issue. Its indeterminateness of sense is not something characteristic of ethical terms in general; it is a problem specifically $[\ldots]$ with the term 'human right'.'

9 James W. Nickel, Making Sense of Human Rights $\left(2^{\text {nd }}\right.$ edn Blackwell Publishing, Oxford 2007) 7. And, even if philosophers attend to the concept of human rights, they 'in the manner of magicians, pull rights out of nowhere' (Griffin (n7) 306).

10 Donald J. Puchala, 'The Ethics of Globalism' The ACUN'S 1995 John W. Holmes Memorial Lecture: Reports and Papers, No. 3. Academic Council on the United Nations System, 1995. www. acuns.org/researchli/johnholmes accessed 4 August 2011.

11 This conference took place in Mexice City on November $6_{20,1947 .}^{\text {th }}$ 
tions; not on the affirmation of the same conception of the world, man, and knowledge, but on the affirmation of the same set of convictions concerning action. ${ }^{12}$

The Universal Declaration of Human Rights was and is not a declaration about common intellectual and philosophical conceptions and ideas, but a pragmatic achievement. The drafting parties agreed on a common and - given the differing views - necessarily theory-free denominator of practical principles. The philosophical underpinnings were sketched only vaguely by putting down on paper that people are born free and equal in dignity and concluding that they have equal and inalienable rights. Why this is so, why human beings are only born, but not conceived free and equal in dignity, and how dignity is the source of rights, nobody really knows. Men, mutually opposed in their theoretical views, came to a pragmatic agreement of what constituted a list of human rights. Maritain's experience that international human rights documents in some sense bypass philosophical debate by simply and pragmatically establishing a set of positive legal norms is corroborated by Freeman who states that 'there is no adequate theory of human rights, and there is a need for greater theoretical rigor' 13 . One cannot help but call this lack of theory a serious deficit - one, which has not been overcome to date.

Why is this deficit problematic? First of all, it hinders concerted action. Whenever actions have to be suited to the word and concrete human rights instruments have to be implemented, having a clear theoretical foundation of human rights becomes unavoidable. The theoretical foundation of human rights is not something that everyone can have his own opinion about as long as one aims for the same rights. In the end, it is the justification and specification, which determines a specific human right's actual meaning and content. It is very likely that the almost insurmountable difficulties in bringing the human rights talk and declarations to life are due to their deficiencies and differences in justification and specification. The second and much more detrimental problem is that 'rights without reasons are vulnerable to denial and abuse' 14 . Without a sound philosophical foundation of human rights, there is no end to the catalogue of human rights and we end up with 'an unruly proliferation of incompatible or often just incredible rights claims' 15 . Given the fact that such a foundation is missing, all kinds of human rights have mushroomed up 'uncontrollably'16 over the last decades: from peace, help in the event of a natural disaster and comprehensive sexual education to euthanasia, globalisation and killing an unborn child based on a woman's right to choose, virtually everything is conceptualised as a human right - the result being an indiscriminate, dubious and quite possibly an irresponsible inflation or hypertrophy of

12 Jacques Maritain, Man and the State (Catholic University of America Press, Washington DC 1998) 77.

13 Michael Freeman, 'The Philosophical Foundations of Human Rights' (1994) 16 Human Rights Quarterly 491, 494.

14 Freeman (n 13) 493.

15 Tasioulas (n 1) 75.

16 James Griffin, 'Discrepancies Between the Best Philosophical Account of Human Rights and the International Law of Human Rights' (2001)101 Proceedings of the Aristotelian Society 1, 2. 
human rights. But: Do we indeed have all these rights? If so, why do we have them? If not, why not? These questions cannot be answered without reference to a theory of human rights, which explicates their foundation. Unfortunately, there is no such philosophical theory.

This article is meant to cure this deficit by enquiring into the philosophical foundation of the concept of human rights and offering a theory of human rights. An obvious starting point for doing so is to focus on the elements of the concept of human rights, namely 'human' and 'right'. A theory of human rights has to be explained with reference to what we mean by 'human rights' and what we mean by 'human rights' (i.e. what is so special about human beings that it warrants granting them such rights). Accordingly, it is my firm opinion that any complete account and justification of the general idea of human rights has to comprise the following two components:

1. The concept of human rights used by this account, whereas this concept has to explained with reference to

- what we mean by 'human rights' and

- what we mean by ' human rights', i.e. what is so special about the human being that we grant him rights.

2. The content of the account, i.e. which human rights are singled out for protection.

In what follows, I shall be mainly concerned with explicating what we are to understand by rights and what is so special about human beings that we grant them the special class of human rights. I shall, however, only touch upon the second component of a theory if human rights and I leave this task for some future article.

\section{The Concept of 'Rights'}

'[L]est we miss the obvious, human rights are rights'. ${ }^{17}$ Without understanding the philosophy of rights, there can be no theory of human rights. The first and fundamental question a theory of human rights has to address is the following: What does the term 'rights' signify? This article will, therefore, start with an analysis of the concept of 'rights'. This task has been alleviated by the work of Wesley N. Hohfeld whose analytical scheme has become "by far the most widely accepted analysis of the logical structure of rights, and [...] is used by the majority of contemporary rights theorists' 18 . Hohfeld ${ }^{19}$ (1913) distinguishes four subclasses ('instances') of rights: the claim-right,

\section{${ }^{17}$ Nickel (2007: 9)}

18 Leif Wenar, 'The Analysis of Rights' in Matthew Kramer, Claire Grant, Ben Colburn, Antony Hatzistavrou, The Legacy of H. L. A. Hart (OUP, Oxford 2008) 253.

19 Wesley Newcomb Hohfeld, 'Some Fundamental Legal Conceptions as Applied in Judicial Reasoning' (1913) 23 Yale Law Journal 16. Wesley Newcomb Hohfeld, 'Fundamental Legal Conceptions as Applied in Judicial Reasoning' (1917) 26 Yale Law Journal 710. 
the liberty, the power and the immunity. This formal distinction between the instances of rights is of paramount importance in any rights-related discussion.

\section{Claim-Rights}

As Dunne \& Wheeler state, the idea of a claim-right (originally called 'right stricto sensu' by Hohfeld) rests on and 'has embodied two foundational claims. First, that there is an identifiable subject who has entitlements; and secondly, that to possess a right presupposes the existence of a duty-bearer against whom the right is claimed.'20 Thus, having a claim-right is to be owed a duty ${ }^{21}$ by another or others. If A has a claimright that $\mathrm{B}$ give him a certain item, then this claim entails that $\mathrm{B}$ has the duty to give $\mathrm{A}$ this item. A claim-right, therefore, is a 'right of recipience'22. This pairing can be expressed in a more formal way as:

A has a claim-right that B should $\varphi^{23}$ iff $^{24} \mathrm{~B}$ has a duty to $\mathrm{A}$ to $\varphi$.

Thus, having a claim-right equals being owed a corresponding duty by another person or persons. This implies that the attribution of claim-rights is meaningless without the possibility of a correlative duty resting somewhere. A Hohfeldian claim-right must thus be specified 'by reference to the actions of the people who bear the correlative duties - rather than to the actions of the people who hold the rights' 25 . When it comes to claim-rights, 'right' and 'duty' are just different names for the same relation, depending on the point of view. Without a duty, there is no claim-right (although there can be a duty without a correlative claim-right).

\section{Liberty-Rights}

In contrast, a liberty-right 26 is a 'right of action'27. This means that if the subjectmatter of one's right is one's own act(s), forbearance(s) or omission(s), that right can-

20 Tim Dunne, Nicholas J. Wheeler, 'Introduction' in Tim Dunne, Nicholas J. Wheeler (eds), Human Rights in Global Politics (CUP, Cambridge 1999) 3.

21 Essentially, a duty is a behavioural constraint: A duty-bearer is not free to act or behave as he pleases; rather, his liberty is constrained by his duty to $\varphi$. To say that B has a duty to $\varphi$ against A is to say that B does not have a choice as to how he should behave towards A. Being under a duty to $\varphi$ is not having a liberty-right to $\varphi$; a duty is the absence of a liberty-right. Although there is more to be said about the concept of duty, this cannot be done within the scope of this article. For more on the concept of duty cf. Christian Erk, Health, Rights and Dignity: Philosophical Reflections on an Alleged Human Right (ontos Verlag, Frankfurt, Paris, Lancaster, New Brunswick 2011) 152ff.

22 David Daiches Raphael, 'Human Rights, Old and New' in David Daiches Raphael (ed), Political Theory and the Rights of Man (Macmillan, London 1967) 56.

23 Where $\varphi$ ('phi') is the behavioural content of the claim-right and stands for a description signifying some behaviour but can also refer to the occurrence of certain states of affairs.

24 i.e. if and only if.

25 Mathew H. Kramer, 'Rights Without Trimmings' in Mathew H. Kramer, Nigel E. Simmonds, Hillel Steiner (eds), A Debate Over Rights: Philosophical Enquiries (Clarendon Press, Oxford 1998) 13.

26 The liberty-right is sometimes also referred to as privilege (according to the original Hohfeldian notation), license, or permission. 
not be a claim-right, but only a liberty-right. ${ }^{28}$ As such, a liberty-right states, what its bearer does not have a duty not to do and gives him a choice (i.e. the liberty) to either $\varphi$ or not to $\varphi$; liberty-rights are the things one may do without being prevented by a duty to the contrary. Having such right 'is to be free of a duty to the contrary'29. Libertyrights 'consist of those actions one is not prohibited from performing' ${ }^{30}$. Expressed more formally:

A has a liberty-right to $\varphi$ iff A has no duty not to $\varphi$.

Although not wrong, the problem with this formulation is that it is coined in the language of a two-term rights talk. Consequently, it forgets the second party necessary for a complete three-term rights talk and is thus underdetermined. But this deficiency can be easily remedied if we remember that a duty is always owed to somebody. The moral significance of A's having a privilege thus is that A is not under a duty toward B to refrain from $\varphi$; A's behaviour is not being constrained by a claim-right of B with respect to $\varphi$. As a consequence, liberties are paired with no-claims: A's having a privilege, i.e. a no-duty towards B, implies B's having a no-claim towards A. This aspect is emphasised by Finnis' definition of a liberty-right:

A has a liberty (relative to B) to $\varphi$, if and only if B has no-claim-right ('a no-right') that A should not $\varphi$. [...] A has a liberty (relative to B) not to $\varphi$, if and only if B has noclaim-right ('a no-right') that A should $\varphi .{ }^{31}$

For example: If A has no duty to vacuum-clean B's flat, i.e. if B has no claim-right towards A obliging A to vacuum-clean B's flat, A is at liberty and has the liberty-right to not vacuum-clean. However, while liberty-rights provide protection for an individual's actions, it would be wrong to conclude that B's having no claim to A's not $\varphi$-ing necessarily means that B has no liberty-right (i.e. has a duty not) to prevent A's $\varphi$-ing. A's privilege does not entail the duty on the part of anyone to not interfere with A's action with respect to $\varphi$. This can also be illustrated by example of the rules of soccer: each team is at liberty to score, i.e. under no duty not to score, but no team is under a duty to let the other team actually do so. On the contrary, each team has the libertyright to prevent this from happening. Another example illustrating the concept of a liberty-right would be to consider a billionaire and a beggar: both have a liberty-right to buy an Aston Martin or to holiday in a luxury resort in the Swiss mountains, although only one of them will actually be able to do so. These examples highlight the crucial difference between liberty-rights and claim-rights: liberty rights are concerned with the right-holder himself, i.e. what he is entitled to do or not to do; claim-rights with what others are obliged to do or not to do with respect to the right holder. Claim-rights are

27 Raphael (n 22) 56.

28 This, strictly speaking, is also true for a power-right (see below).

29 Peter Jones, Rights (Macmillan Press, London 1994) 17.

30 Andrew Fagan, 'Human Rights' in The Internet Encyclopedia of Philosophy, 2006. www.iep.utm. edu/h/hum-rts.htm accessed 3 August 2011.

31 John Finnis, Natural Law and Natural Rights (2 ${ }^{\text {nd }}$ edn OUP Oxford 1982) 199. 
specified by reference to the actions of the people who bear the correlative duties, liberty-rights by reference to the actions of the people who hold the rights. In other words, claim-rights are correlative to duties and liberties are limited by duties.

\section{Power-Rights}

Having a power-right is the 'ability to cause by an act of one's own, an alteration in a person's rights, either one's own rights or those of another person, or both' 32 . An agent's power-right can therefore make another person or himself have, cease or alter a liberty-right or a claim-right (and thereby create, change and if necessary enforce or abolish a duty). A democratic parliament enacting a new tax law is a classic example of exercising a power-right, since the parliament imposes on the citizens the duty to pay the kind and amount of taxes that have been enacted. Furthermore, powers can also put somebody in a position to not only be able to alter first-order, but also second-order incidents. A chain of command, as e.g. found in the military, would be an example of such a power. A higher-ranking officer has the power to relieve a lower-ranking one from his duties and thereby annul the powers of the latter. Cruft explains this as follows:

$\mathrm{X}$ holds a power if and only if $\mathrm{X}$ holds the ability to create or to remove some claim, duty or privilege (a claim, duty or privilege which might be held by $\mathrm{X}$ himself or herself, or by someone else), or X holds the ability to create or to remove some power, liability, disability, or immunity (a power, liability, disability or immunity which might be held by $\mathrm{X}$ himself or herself, or by someone else). ${ }^{33}$

\section{Immunity-Rights}

In contrast to having a power, 'for $\mathrm{X}$ to have an immunity against $\mathrm{Y}$ is for $\mathrm{Y}$ to lack a power as regards $X^{\prime 34}$. An immunity-right protects from the power of others to alter one's rights or duties. If there are inalienable rights then we all lack power against ourselves and thus have immunities with respect to these rights. An immunity-right can be said to exist if the rights-holder is not liable to have his rights-status changed (e.g. by means of a prohibition to exercise an existing power-right or by means of a prohibition to actually create power-rights) by the action of another person utilising a power-right. In the style of the above mentioned definition of a power-right this can be expressed more formally as follows:

A has an immunity-right (relative to B's $\varphi$-ing) iff B has no power-right (i.e. a disability) to create or to remove some claim, duty or privilege (a claim, duty or privilege which might be held by A himself or herself, or by someone else), or iff B has no

32 Judith Jarvis Thomson, The Realm of Rights (Harvard University Press, Cambridge (Mass.) 1990) 57.

33 Rowan Cruft, 'Rights: Beyond Interest Theory and Will Theory?' (2004) 23 Law and Philosophy 347,351 .

34 Thomson (n 32) 59. 
power-right (i.e. a disability) to create or to remove some power, liability, disability, or immunity (a power, liability, disability or immunity which might be held by B himself or herself, or by someone else).

\section{Molecular or Cluster-Rights}

Although all assertions or ascriptions of rights can be understood in terms of these four Hohfeldian instances, i.e. can be reduced without remainder to ascriptions of one of these categories, it would be wrong to suppose that every right must exist in one and only one pure Hohfeldian. As reality shows, many rights assertions are covered by a number of these instances at the same time. The right to freedom of movement, for instance, is a liberty (I am under no duty not to move and thus free to move), a powerright (to alter my legal status as a citizen) as well as an immunity (against anyone trying to introduce laws hindering my travelling). Consequently, we have to add a fifth instance: the 'molecular right' 35 or 'cluster-right' 36 , which is a combination of two or more of the four basic (or as Wenar calls them 'atomic'37) Hohfeldian incidents of rights.

\section{Further Analytical Characteristics of Rights}

Obviously, the content of rights can vary a great deal. These further properties, not covered by the Hohfeldian scheme of analysis, have been captured by the following further distinctions:

- The first distinction is between active and passive rights, i.e. rights to do things and rights to have things done for or to one. Active rights allow the right-bearer to take a certain action or behave in a certain way, whereas passive rights oblige another party or parties. According to this classification, the liberty and the power are active rights, which the right-bearer exercises, in contrast to the claim and the immunity which are passive rights enjoyed by the right-bearer.

- A second distinction answers the question, 'Against whom is a right held?'. This distinction is one between 'rights in personam' and 'rights in rem', whereby in personam rights are held exclusively against some specifically identified duty-bearer, i.e. a specific person or persons, and the latter against no one in particular, but people at large; the term 'in rem' does not denote the subject of the right, but the compass: 'it denotes that the right in question

35 Leif Wenar, 'The Nature of Rights' (2005) 33 Philosophy and Public Affairs 223, 225.

36 Thomson (n 32).

37 Wenar (n 36) 225. 
avails against persons generally; and not that the right in question is a right over a thing'. ${ }^{38}$

- A third distinction discerns 'individual rights' and 'group rights' (or collective rights). Group rights are held by a group rather than severally by its members, whereas individual rights - as the term implies - are held by a single individual.

- A forth distinction, which is only applicable to the class of claim-rights is the one between positive ${ }^{39}$ and negative rights, where a positive claim-right corresponds to a positive duty and a negative claim-right to a negative duty. The former requires the respective agent's performance and the latter the agent's forbearance: 'A claim-right is always either, positively, a right to be given something (or assisted in a certain way) by someone else, or negatively, a right not to be interfered with or dealt with or treated in a certain way, by someone else.' 40 According to this distinction, negative claim-rights imply a duty to non-interference or 'negative action' 41 . They give the claim-rightholder the right to keep something, which he already possesses, whereas positive claim-rights as claims to something (e.g. good, service, result) imply a duty to undertake a specific positive action and give the claim-right-holder a right to something he does not yet possess or to enable him.

\section{What makes a Right a Human Right?}

In the previous sections, we carved out what makes a human right. But what makes a right human? This is the question this chapter is meant to answer. Our enquiry could start, for example, with the right not to be murdered. As intuition and experience tells us, this right has both legal and non-legal sources; it is usually assigned by a legal system, but would exist even if no legal system would establish it. There is something about this right 'even all governments together cannot legislate [...] out of existence'42 and no custom can deny. The fact that there is something that goes beyond the realm of legal as well as customary rights, has been understood and recorded since the earliest history of mankind - and this something is usually called moral right. When speaking about rights we should, therefore, not only bear in mind that there are claim-rights,

38 John Austin, 'Lectures on Jurisprudence or The Philosophy of Positive Law: Volume 1' $\left(5^{\text {th }}\right.$ edn John Murray, London 1885) 370. In order to avoid this confusion, Hohfeld calls in personam rights 'paucital rights' and in rem rights 'multital rights' (Hohfeld (n 19) 718).

39 The term 'positive' is not to be confused with the term 'positive' in 'positive law'. Whereas the former is meant to express that the corresponding duty is one of commission (and therefore contrary to negative rights, which are about duties of forbearance), the latter signifies codified law as contrasted with conventional or moral law.

40 Finnis (n 31) 200.

41 Jones (n 29) 15.

42 Thomas Pogge, 'Recognized and Violated by International Law: The Human Rights of the Global Poor' (2005) 18 Leiden Journal of International Law 717, 718. 
liberty-rights, immunity-rights, power-rights and cluster-rights but also that we can distinguish between in moral, legal and customary rights. The best path towards gaining an understanding of the concept of moral rights and of its conceptual differences with respect to both legal and customary rights is to ask why we have rights, i.e. to enquire into the sources of rights and duties.

\section{Legal, Conventional and Moral Rights}

On an abstract level, rights and duties can either be conventional, i.e. formed by customs, agreement or compact, non-conventional, i.e. formed by authoritarian decree, or pre-conventional, i.e. independent of agreement or authority. Furthermore, the same right or duty can either be positive, i.e. existent only because of some form of legislation or codification, or pre-positive, i.e. existent independent of and prior to any legislation. Following these initial distinctions allows us to distinguish between the following - as far as I can tell: exhaustive - three categories of rights. As we shall see, although all three categories of rights and duties can have the same content (e.g. the right to not be murdered), there is a difference in the way they are constituted and validated - a difference which results in an opportunity for logical prioritisation.

\section{- $\quad$ Positive (= legal) rights and duties}

These rights are called 'positive' because they derive from the laws of the society and have been posited by human will institutionalized in some form of government - whose power is usually limited to a certain geographical area. A positive right or duty cannot be said to exist prior to its inclusion in a legal code, i.e. its existence, validity and applicability is dependent upon codification by some form of legislature. Furthermore, positive rights and duties are necessarily backed by some form of jurisdiction in relation with institutionalised penal or rectifying actions for non-compliance.

Positive rights can either be conventional (e.g. democratic positive law), i.e. emanating from social conventional efforts or non-conventional (e.g. the positive law of a tyrant not requiring any conventional agreement, but rather the capacity to enforce it). Positive law and its derivative rights is authoritarian law, i.e. imposed from the top - with varying degrees of consent from the bottom. The rationale for its existence is political and thus contingent upon the balance of power within a state. It could thus be enacted and enforced by a powerful minority against the will of a less powerful majority, by a powerful majority against the common will of less powerful minorities or, in an ideal case, by complete societal consent.

Based on these comments, it is easy to see that all legal rights are positive rights; therefore, both expressions can be used synonymously. Because of their positive nature, positive rights and duties are culturally and politically relative because they are contingent upon local laws, customs or beliefs.

\section{- Pre-positive conventional rights and duties}

The category of pre-positive conventional rights is congruent with what are commonly called customary rights. They are aspects of local customs, based on 
widespread acceptance and reciprocity and thus rooted in shared behavioural patterns. This means that they are necessarily conventional in nature. In contrast to the authoritarian positive law, customary law can be described as bottom-up law.

As far as their existence and validity is concerned, they are pre-positive, i.e. not dependent on inclusion in a society's legal code. Positive law acknowledges the existence of customary rights and duties and generally accepts them if they are repeated for a long time ('longa consuetudo') and if they have acquired the force of tacit and common consent ('opinio juris').

Given their combined pre-positive and conventional nature, customary rights are - just as legal ones - also culturally and politically relative. Given their relativity, I am inclined to call customary rights the weak form of pre-positive rights and duties.

\section{- $\quad$ Pre-positive pre-conventional rights and duties}

This category is equal to the one of moral rights and duties. Pre-positive preconventional rights and duties exist independently of any legal code and are not contingent upon the laws of a society nor rooted in or constituted by a set of rules of a given society - which sets them apart from mere positive rights. They exist, regardless of their reproduction in positive law. Rather, positive law or social institutions, which fail to protect them, are defective. Conversely, this means that positive law is required to protect and promote them. Furthermore, pre-positive pre-conventional rights are not the result of customs, agreement or compacts, which makes them distinct from pre-positive conventional rights. They exist, regardless of their reproduction in customary law.

We could say that moral rights and duties are not only pre-positive, but also pre-conventional and therefore logically prior to customary rights. Because they are not posited and not conventional, they lack the relativity inherent to the two categories of rights above and can also be said to constitute the strong form of pre-positive rights.

However, if moral rights and duties do not gain their power from a legal code or from being conventional in nature, they need another source of validation. This source is that they are being derived from moral reasons or better: a moral theory.

In a nutshell, a moral right can be understood as a right, "which is not the product of community legislation or social practice, which persists even in the face of contrary legislation or practice, and which prescribes the boundary beyond which neither individuals nor the community may go in pursuit of their overall ends' 43 .

These findings can be summarised in the following matrix (cf. Figure 1):

43 Raymon G. Frey, Interests and Rights: The Case Against Animals (Clarendon Press, Oxford 1980) 7. 


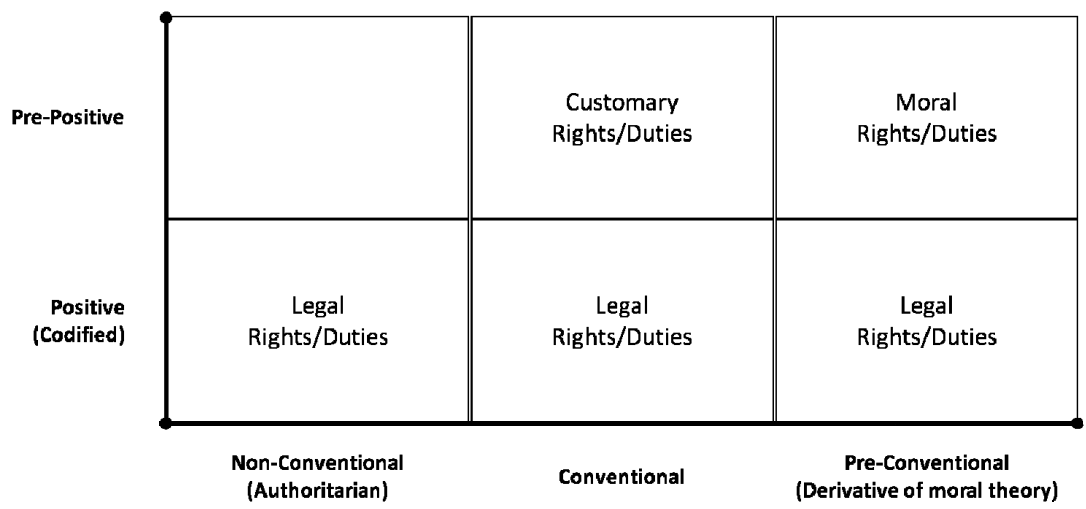

Figure 1: Categories of Rights and Duties

These finding put us in a position to establish the following ranking: pre-positive pre-conventional rights are prior to pre-positive conventional rights, which are prior to positive rights. Or in a more comprehensible version: moral rights are prior to customary rights, which are prior to legal rights. Or in the most comprehensible version: moral rights override all other categories of rights. They are necessarily universal. Given this universality, both customary as well as legal rights should ideally be mere expressions of pre-positive law.

\section{The Analytics of Moral Rights}

Having established the existence of moral rights, the next question we have to deal with is whether we can apply the Hohfeldian analytical framework as introduced above to this category of rights as well or whether we have to make some modifications to it. For, a weakness of this scheme is that it has been developed aimed at incorporating legal rights and duties.

Some writers (such as Thomson) have suggested adopting the Hohfeldian incidents for moral rights as well. ${ }^{44}$ But as Jones ${ }^{45}$ has shown, the Hohfeldian typology, though applicable, is less central to the concept of a moral right than it is for a legal right - at least if considered in its wholeness. This can be easily seen in the case of power-rights: although I might have the freedom to enter into promises (which is a liberty-right), I certainly do not have the power to establish that promises do not have to be kept in general. This would be contrary to the pre-positive and pre-conventional nature of moral rights and duties. Consequently, it would be true to state that when it comes to moral rights everyone has an immunity-right, since no one is in a position to change someone's moral position. It is a characteristic of moral rights that they are inaccessible

44 Thomson (n 32) 74.

45 Jones (n 29) $47 f$ 
to changes by either authoritarian or conventional human will. Powers and immunities can be derivative of moral rights, but a power-right cannot introduce, change or annul a moral right or duty.

In order to keep things simple and avoid confusion, I propose to exclude both power- and immunity-rights, i.e. 'second-order' incidents, from the category of moral rights and duties. Where there is no general power over one's moral rights/duties, there is no need for a general immunity-right. For the purpose of this thesis, moral rights/duties are instances of either claim-rights or liberty-rights, i.e. 'first-order' incidents of rights (whereas their further characteristics, as outlined above, are valid as well). This is also in line with Dworkin ${ }^{46}$ who differentiates between moral rights 'in a weak sense' and moral rights 'in a strong sense': a moral right in the weak sense would be what has been described above as a liberty-right, a moral right in the strong sense is a claim-right, which imposes duties on others.

If moral rights cannot be 'second-order', but only 'first-order' incidents, this leaves three options for a philosophical understanding of moral rights: a moral right can either be

1. a moral claim-right (which necessarily implies a corresponding duty):

A has a moral claim-right that B should $\varphi$ if and only if B has a moral duty to A to $\varphi$,

2. a moral liberty-right:

A has a moral liberty-right to $\varphi$ if and only if A has no moral duty not to $\varphi$, or

3. a moral molecular right/cluster-right, i.e. a combination of a moral claim-right and a moral liberty-right

We also know that rights can be divided into active and passive, rights in personam and rights in rem, individual and group rights as well as positive and negative rights. To recapitulate briefly: the classes of active (A has a right to $\varphi$ ) and passive rights (A has a right that $\mathrm{B} \varphi$ ) correspond to the distinction between liberty-right and claim-right; liberty-rights are active rights and claim-rights are passive rights. Rights in personam are held against a specific person or persons, while rights in rem are held against people at large. The distinction between individual rights and group rights answers the question of who actually holds rights: an individual right is held by an individual, group rights are held by a group rather than by its members severally. ${ }^{47}$ Negative rights imply a negative duty to non-interference or forbearance on the part of the duty-bearer (negative action), positive rights as claims to be given something or assisted in a certain way obligate the duty-bearer to undertake a specific positive action. Given the necessity of a duty-bearer, negative and positive rights can only be claim-rights. If we apply these distinctions to the three options for a philosophical understanding of human rights listed above, we are led to think that there are - in theory - four moral claim-rights

46 Ronald Dworkin, Taking Rights Seriously (Gerald Duckworth, London 1977) 188ff.

47 The distinction between individual and group rights is of no further interest for the purpose of this article. 
(moral positive claim-right in rem, moral negative claim-right in rem, moral positive claim-right in personam and moral negative claim-right in personam), two moral liberty-rights (moral liberty-right in rem, moral liberty-right in personam) and one moral cluster-right. But this does not correspond with reality and overestimates the possibilities we have in conceptualising moral rights.

For, the distinction between rights in rem and rights in personam has certain implications for the definition of a right as positive or negative or as Salmond formulates it: 'is closely connected with that between positive and negative rights'. ${ }^{48}$ The connection between rights in rem/rights in personam and positive rights/negative rights basically is that 'the duties which correlate with rights in rem are always negative: that is to say they are duties to forbear or abstain'49. Therefore, conceptually speaking, there is no such thing as a positive claim-right in rem. That claim-rights in rem can only be negative is an almost necessary consequence of the nature of a right in rem. As has been said, rights in rem are universally claimable and held against persons universally. Now, if rights in rem involved positive duties, then every such duty would either set the whole world in motion or involve universal liability for non-compliance. This would be absurd because overly demanding - especially in a world with scarce resources as the one we live in. Thus, a claim-right in rem is always negative, i.e. the only corresponding duty of a claim-right in rem is the negative duty resting upon all men not to interfere with the right: rights 'available against all other persons, can be nothing more than a right to be left alone by those persons [...] The only duties, therefore, that can be of general incidence are negative. ${ }^{50}$ A claim-right in rem can only constitute a duty requiring forbearance or omissions on the duty-bearer's part; or put differently: positive claim-rights can only be in personam while negative claim-rights can either be in rem or in personam.

This line of reasoning, however, might not be a completely convincing attempt to disprove the conceptual possibility of positive claim-rights in rem. We should, therefore, take this thought one step further and ask whether there are moral positive claimrights at all; if there is no such thing as a moral positive claim-right, then neither are there moral positive claim-rights in rem nor in personam. In trying to find an answer to this question, it is interesting to note that while there is unanimity concerning the existence of negative moral claim-rights, there is considerable disagreement with regard to the validity of ascriptions of moral positive claim-rights. Some, such as Cranston or Pogge 51 , hold that moral and human (and thus moral) rights cannot ground positive duties, but only impose negative duties. Cranston holds that the ascription of positive

48 John W. Salmond, Jurisprudence ( $6^{\text {th }}$ edn Sweet and Maxwell, London 1920) 203. Given the fact that the positive/negative distinction can only apply to claim-rights, this implication and connection only concerns claim-rights.

49 Austin (n 38) 371.

50 Salmond (n 48) 203.

51 Maurice Cranston, 'Are There Any Human Rights?' (1983) 112 Daedalus 1, 12. Pogge (n 42) 720. 
rights leads to a reduction of moral rights to 'the status of ideals' 52 and that their realisation is not possible: 'for a government to enforce them, it would need to have access to great wealth, wealth that most governments of the world have no means of acquiring'53. Pogge 54 furthermore holds that many of the states of affairs that lead philosophers and politicians to argue for positive duties of assistance are in fact the result of severe violations of negative duties. As it seems, the concept of moral positive claimrights is either theoretically unsound or not needed, since an adherence to the prescriptions of moral negative claim-rights would do the trick. In my opinion, there can be conceptually speaking - no moral positive claim-rights, be it in rem or in personam. 55 The main argument against the existence of moral positive claim-rights is that they clash with many critical moral negative claim-rights, especially the right to freedom and property. This argument has been expressed well by Griffin who - although basically arguing for welfare rights - states:

Welfare rights would require substantial transfers of goods. [...] But there is the familiar point that, by and large, goods do not appear on the scene like manna from heaven. For the most part, there is no wealth to transfer, unless it has first been created. It therefore comes into the world already owned. And it comes into the world, to some extent, because it can be owned. To put it in a rough, intuitive way, there is something odd, even at times morally wrong, in ignoring ownership. ${ }^{56}$

At their very bottom, moral positive claim-rights imply that one has an undeniable right to take from or to be given by another that which is not his and which one has not earned; they are rights of recipience. But what is claimed is not lying around like manna from heaven, but resources, which are necessarily already owned. Understood like this, moral positive claim-rights are a positive form of property right - the right to be given some form of resources and thus property. However, they are not only a form of a positive property right, but also presuppose the notion of private property; for, if everything were common, such a right would be utterly unnecessary. The right to be given something by somebody else only makes sense if the counterpart has dominion over the 'something' in question, i.e. is in a position to give it. If there were no private property, no one would have the power to give the claimant what he has a moral positive claim-right to, since everything would be owned by no one. Now, the institution of private property only makes sense if there is such a thing as a moral negative claimright with respect to property. Understood like this, every moral positive claim-right presupposes a right not to be deprived of one's property. But, if this is so we are stuck

52 Cranston (n 51) 12.

53 Cranston (n 51) 13.

54 Pogge (n 42). Thomas Pogge, 'World Poverty and Human Rights' (2005) 19 Ethics and International Affairs 1. Thomas Pogge, 'Severe Poverty as a Violation of Negative Duties (Reply to the Critics)' (2005) 19 Ethics and International Affairs 55.

55 For a lengthy treatment of this question and a more detailed account of my position on this cf. Erk (n 21 ) 183-207.

56 James Griffin, 'Welfare Rights' (2000) 4 The Journal of Ethics 27,37 
with an unsolvable conundrum: if $\mathrm{A}$ has the right to enjoy his property and $\mathrm{B}$ has the right to some share of A's property, which claim should be given priority? Regardless of one's choice, one always violates the rights of somebody else. This leaves only two options: one has to either abandon the moral negative claim-right to freedom, which includes the free use of one's property or the concept of private property altogether, or one has to give up the idea that there is such a thing as a moral positive claim-right. The first option is not a viable one: firstly, there has been a long philosophical tradition asserting the existence of a moral negative claim-right to freedom and property; and secondly, such a negative right can be easily derived from the account of moral rights/duties offered below. This only leaves the second option. There is something at odds with the whole idea of moral positive claim-rights, i.e. the moral claim that I should be given something without having done anything to deserve it. Arguing for moral positive claim-rights would be defending involuntary charity. Unless there are strong arguments for the existence of moral positive claim-rights, we should therefore abandon the notion that such moral rights exist.

In consequence, moral claim-rights are always negative in nature. They protect people against being treated in certain ways, but do not entitle them to the support of others - although there is an exception to the rule, namely in cases of extreme necessity57. Generally, positive rights do not exist as pre-positive and pre-conventional rights; but they can exist as conventional and/or positive (in the sense of legal) rights. This means they do not exist, until they have been agreed to exist, promised, contracted, enacted (i.e. arise from voluntary and free actions, transactions or commitments), arise as remedy for a former rights violation ('restitutio', i.e. an act of commutative justice) or come into existence as the result of special relations or situations (e.g. an infant has undertaken no voluntary or free act in order to being conceived and borne, but shares in the same positive rights as any other member of the family and - on a higher level - the community he is part of). It should be emphasised that defending this view is not to advocate, speak in favour of or be motivated by a spirit of stinginess. Stating that there are no moral positive claim-rights is just saying that there cannot be a moral right to be given something, nothing more and nothing less. However, this position does not and cannot establish in any way that there is no such thing as a moral positive duty, i.e. a duty to help and give something to somebody (sometimes also called 'duty of charity'). It only establishes that such a duty would have to be an imperfect one, i.e. one with no claim-right corresponding to it, and that such a duty cannot be rooted in or the result of a moral positive claim-right.

\section{Human Rights and Duties as a Special Class of Moral Rights and Duties}

So far, we have only been speaking about legal, conventional and moral rights. But this article is not about legal, conventional or moral rights, but human rights. So, how do human rights fit into this triad of rights? What does the addition of 'human' to 
'rights' signify? What kind of right is a human right? Is it a legal, conventional or moral right?

When we think about human rights, what comes to our mind first might be the United Nation's Human Rights Declaration or the European Convention on Human Rights (ECHR). Therefore, human rights are often taken to be legal rights. However, as Fagan rightly points out, equating human rights with legal rights would be 'philosophically naïve' 58 . As is commonly agreed upon in the philosophical and political community, human rights are rather thought of as a subclass of moral rights: 'human rights are a form of moral rights' ${ }^{59}$ As such, they are independent from convention and legal confirmation and 'exist independently of acceptance or enactment as law' 60 . They establish values that positive and conventional law should adhere to and limits beyond which they cannot go. But, the moral nature of human rights does not exclude, of course, the possibility of codification. Human rights can also be positive or conventional rights where they are buttressed by positive or conventional law - but their existence is not dependent on their acknowledgement by law, government or society. Rather, they serve as a yardstick for and as an ideal by which any codified or conventional right should orientate itself. Having a human right then means that this human right ought to be recognised or at least protected by positive or conventional law as well; not doing so means committing a moral wrong: 'The space protected by human rights is what it is right that people should enjoy.' 61 So, human rights are a special class of the moral rights of human beings (although they are not the only moral rights that exist). All human rights are moral rights of human beings, but not all moral rights of human beings are human rights. ${ }^{62}$

\section{Human Rights and Human Dignity}

So far, it has been established what rights are and what distinguishes moral from both customary and legal rights. It has also been established that moral rights are grounded in and justified by a moral theory. The special class of human rights is usually justified with reference to a moral status theory, i.e. a moral theory that holds that 'human beings have attributes that make it fitting to ascribe certain rights to them, and

58 Fagan (n 30).

59 Maurice Cranston, What Are Human Rights? (Bodley Head, London 1973) 21. In the same fashion, Nickel and Orend state that human rights are 'characterized as moral rights' (Nickel (n 9) 46) and 'high priority moral rights' (Brian Orend, Human Rights: Concept and Context (Broadview Press, Petersburg, Ontario 2002) 67). Also cf. Sen (Amartya Sen, Development as Freedom (OUP, Oxford 2001) 229): 'It is best to see human rights as a set of ethical claims, which must not be identified with legislated legal rights.'

60 Nickel (n 9) 45.

61 R. J. Vincent, Human Rights and International Relations (CUP, Cambridge 1986) 11.

62 If human rights are a special class of the moral rights of human beings, this means that there are moral rights, which are not of human beings. Animal rights are moral rights, but not moral rights of human beings. 
make respect for these rights appropriate'63. The attribute that makes it fitting to ascribe human rights to human beings is usually taken to be human dignity. Therefore, we are in a position to sharpen our account of human rights developed above; human rights are that special class of the moral rights of human beings which is justified with reference to the dignity of human beings. 64

\section{The Foundation of Human Rights in Human Dignity}

The concept of 'dignity' is the normative and philosophical linchpin of justifying human rights. This relation between human rights and human dignity is also confirmed by Gewirth: 'The relations between human dignity and human rights are many and complex, but one relation is primary: human rights are based upon or derivative from human dignity. It is because humans have dignity that they have human rights. ' 65 Without reference to human dignity, one cannot gain an adequate understanding of human rights: 'Dignity is the ground of rights, not a synonym for rights.' 66 Sulmasy goes on to emphasise the close relation between human rights and human dignity: 'to speak clearly of human rights, one must have a clear conception of human dignity. The intimate relationship between these two concepts can be stated simply: People do not have dignity because they have rights; they have rights because they have dignity. [...] Dignity is prior to rights. [...] All human rights depend upon the concept of human dignity.'67

Yet, although more than 60 international conventions and human rights documents invoke the concept of 'human dignity' to justify the rights asserted in them, they neither explicitly define the meaning or content of nor justify the term 'human dignity'. 68 Jacobson corroborates this observation. He remarks that although an evaluation of the history of the drafting of the UDHR based on contemporaneous documents and accounts allows for the conclusion that dignity was a standard applied throughout the process of debating and writing each of the Declaration's thirty articles, 'it is less clear that the drafters ever engaged in a discussion about the meaning of dignity itself' 69 . Therefore, although almost everyone gives at least lip service to the ideal of human

63 Leif Wenar, 'Rights' in The Stanford Encyclopedia of Philosophy, 9 July 2007 http://plato.stan ford.edu/entries/rights accessed 3 August 2011.

64 This necessitates the conclusion that not all moral rights held by human beings are necessarily human rights, but only those, which actually arise from human dignity, since there may be moral rights of human beings, which may be grounded differently.

65 Alan Gewirth, 'Human Dignity as the Basis for Rights' in Michael J. Meyer, William A. Parent (eds), The Constitution of Rights: Human Dignity and American Values (Cornell University Press, Ithaca and London 1992) 10.

66 Daniel P. Sulmasy, 'Human Dignity and Human Worth' in Jeff Malpas, Norelle Lickiss (eds), Human Perspectives on Human Dignity: A Conversation (Springer, Dordrecht 2007) 10.

67 Sulmasy (n 66) 25.

68 Cf. Doron Shultziner, 'Human Dignity - Functions and Meanings' (2003) 3 Global Jurist Topics 1 as well as Jonathan Mann, 'Dignity and Health: The UDHR's Revolutionary First Article' (1998) 3 Health and Human Rights 31.

69 Nora Jacobson, 'Dignity and health: A Review' (2007) 64 Social Science \& Medicine 292, 295. 
dignity, the foundations for that principle are seldom explicated. The concept of dignity appears in a wide variety of guises, many of which seem to be at odds with each other. As it seems, the justificatory mechanism for our human rights is a philosophical terra incognita whose meaning is 'left to intuitive understanding, conditioned in large measure by cultural factors' 70 . Unfortunately, this renders the concept of human dignity and, in consequence, human rights arbitrary and useless. In order to save the idea of human rights one has to, therefore, offer a philosophical account of human dignity.

\section{Understanding Human Dignity}

So, what is human dignity and how are human rights and human dignity related to each other? Dignity is not something accessible to empirical measurements or something like an organ, which can be discovered in our body. Furthermore, it is 'not a distinct property or quality, like a body's color, or an organ's function'71. Rather, it refers to a property or properties, which 'cause one to excel, and thus elicit or merit respect from others' 72 and by which one is considered worthy, honourable or estimable. It thus implies and connotes terms such as worthiness for honour or esteem, elevation, excellence and distinction. It is a special kind of value, an exalted value, even an excellence of value. Value as opposed to disvalue indicates positive importance, whereby the term 'importance' designates 'that quality or characteristic of a thing that makes it not neutral and, lifting it out of neutrality, provides the ground of meaningful motivation' 73 . In the same fashion, Kass states that dignity conveys 'a special standing for the beings that possess or display it [...] something elevated, something deserving of respect' 74 . To make a long story short: Human dignity refers to those properties of man, which lift him out of neutrality; it is a term of distinction - both with respect to the rest or creation as to his fellow men. Attaching human rights to the high value, which is the dignity of human beings, is to envelope the dignity in a protective capsule; but it also means that the exalted value of the dignity of human beings enveloped into a right is so important that it trumps other values.

Which excellences or elevations are at the heart of human dignity and give their bearers special worth and standing as well as human rights? What is it that makes human beings worthy of our respect? Throughout history, we can find different perspectives on why man is lifted out of neutrality:

70 Oscar Schachter, 'Human Dignity as a Normative Concept' (1983) 77 The American Journal of International Law 848, 849.

71 Patrick Lee, Robert P. George, 'The Nature and Basis of Human Dignity' in The President's Council on Bioethics (ed), Human Dignity and Bioethics. Essays Commissioned by the President's Council on Bioethics (The President's Council on Bioethics, Washington DC 2008) 409f.

72 Lee, George (n 71) 410.

73 Josef Seifert, What is Life? The Originality, Irreducibility and Value of Life (Rodopi, Amsterdam and Atlanta 1997) 95.

74 Leon R. Kass, 'Defending Human Dignity' in The President's Council on Bioethics (ed), Human Dignity and Bioethics. Essays Commissioned by the President's Council on Bioethics (The President's Council on Bioethics, Washington DC 2008) 308. 
- In his 'De Officiis' Cicero writes: 'Atque etiam, si considerare volumus, quae sit in natura excellentia et dignitas, intellegemus, quam sit turpe diffluere luxuria et delicate ac molliter vivere, quamque honestum parce, continenter, severe, sobrie.' 75 For Cicero, dignity is based on one's excellence as a human being.

- In his 'Leviathan', Thomas Hobbes defined dignity in a very different way: 'The value or worth of a man is, as of all other things, his price; that is to say, so much as would be given for the use of his power, and therefore is not absolute, but a thing dependent on the need and judgement of another. [...]. The public worth of a man, which is the value set on him by the Commonwealth, is that which men commonly call dignity.' 76 (Hobbes, 1991: 63 (chapter 10)) For Hobbes dignity is the value one has to others; therefore, it is dependent on an external valuation and subject to the market price.

- A third view of dignity is presented by Immanuel Kant: 'Das aber, was die Bedingung ausmacht, unter der allein etwas Zweck an sich selbst sein kann, hat nicht bloß einen relativen Werth, d.i. einen Preis, sondern einen innern Werth, d.i. Würde'. ${ }^{77}$ For Kant, dignity is inherent to man and not dependent on external valuation or one's degree of human excellence. Dignity in this sense cannot be gained, lost and/or regained - one just has it.

These three historical uses of the word 'dignity' are illustrative of the three senses or facets according to which dignity is generally understood in axiology and moral philosophy. In principle, the dignity of human beings can be divided into inherent or intrinsic, inflorescent as well as attributed/bestowed dignity ${ }^{78}$ :

- Intrinsic/ontological dignity:

By this kind of dignity we mean the 'value that human beings have simply by virtue of the fact that they are human beings' 79 . This kind of dignity can be discovered, but not generated. It signifies a human being's respect-worthiness which is independent from our subjective preferences: 'the value called 'dignity' is an intrinsic preciousness and goodness of a being that is in no way dependent

75 Cicero, De Officiis, Liber 1, 106. This translates as: If we wish to reflect on the excellence and dignity of our nature, we shall realize how dishonorable it is to sink into luxury and to live a dainty and soft lifestyle, but how honorable to live thriftily, strictly, with self-restraint, and soberly.

76 Thomas Hobbes, Leviathan (CUP, Cambridge 1991) 63 (chapter 10).

77 Immanuel Kant, 'Grundlegung zur Metaphysik der Sitten (1785)' in Akademieausgabe von Immanuel Kants Gesammelten Werken, Band 4, http://www.korpora.org/Kant/verzeichnisse-gesamt.html accessed 3 August 2011, Ak 435. This translates as: That which constitutes the condition under which alone something can be an end in itself has not merely a relative worth, i.e. a price, but has intrinsic worth, ie dignity.

78 Cf. Erk (n 21) 236ff.

79 Daniel P. Sulmasy, 'Dignity and Bioethics. History, Theory, and Selected Applications' in The President's Council on Bioethics (ed), Human Dignity and Bioethics. Essays Commissioned by the President's Council on Bioethics (The President's Council on Bioethics, Washington DC 2008) 473. 
on our subjective likes or dislikes' 80 . While some things may be lifted out of the neutral only subjectively - insofar as they e.g. please or displease us or are agreeable or disagreeable to us - others may not and are objectively lifted out of the neutral 'by an objective in-dwelling positive importance'81. As I have argued elsewhere 82 , this objective in-dwelling positive importance can only consist in every human being's being a person, i.e. in being an individual substance of a rational nature. This is the only criterion which meets the requirement that this aspect of dignity is to be intrinsic. Human beings possess this kind of dignity not only when they function as a person, but by virtue of being one. Therefore, ontological dignity is grounded in the substantial being of a man and its potencies, and not only their actualisation. When it comes to the ontological dignity of a person, this value is not contingent on age, consciousness, illness or our subjective inclinations. It is unconditional. It is the substantial being of a man, which grounds his personhood and thus his ontological dignity; consequently, ontological dignity is always had by all human beings. It is an inherent endowment of every human being.

\section{- Inflorescent dignity:}

Sometimes, dignity is also used to refer to a state of virtue or 'to individuals who are flourishing as human beings - living lives that are consistent with and expressive of the intrinsic dignity of the human' 83 . On the one hand, this flourishing lies in the conscious actualisation of the person's capabilities; as such it is based on the actualisation of the potential of the rationality, which is characteristic for persons ${ }^{84}$. This aspect can, therefore, be called the dignity of awakened personhood or the dignity of actual rational consciousness. In contrast to the first source of human dignity and human rights, this second source can be lost in case of e.g. coma; it can, therefore, not be considered inalienable. On the other hand, inflorescent dignity consists in what can be called acquired dignity and which is all about the way a person utilises his (awakened) personhood. As such it does not automatically belong to persons, but has to be conquered through morally good conduct; in consequence, it is not inalienable and can be lost, too.

80 Josef Seifert, 'The right to life and the fourfold root of human dignity' in Juan de dios Vial Correa, Elio Sgreccia (eds), The Nature and Dignity of the Human Person as the Foundation of the Right to Life. The Challenges of the Contemporary Cultural Context. Proceedings of the VIIIth Assembly of the Pontifical Academy for Life (Vatican City, 25-27 February 2002) (Libreria Editrice Vaticana, Vatican City 2002).

${ }^{81}$ Seifert (n 73) 96.

82 Erk (n 21) $237 \mathrm{ff}$.

83 Sulmasy (n 79) 473.

84 This potential mainly consists in eg self-awareness (reflexivity, distinguishing between self and something), reason (rationality in the sense of thinking, communication, intelligent cognition as well as cognition of truth, consciousness and self-knowledge (which is the basis for self-awareness)), freedom, 


\section{- Bestowed/attributed dignity:}

This kind of dignity refers to the value 'that human beings confer upon others by acts of attribution'85; it comprises dignity resulting from social roles and functions (e.g. the dignity of a judge). It is a created, conventional and subjective form of value. The Hobbesian version of dignity is attributed. However, bestowed dignity also comprises dignity resulting from gifts not attributed by man, such as natural gifts (e.g. beauty, intelligence, genius or charm, strength of character) or gifts attributed by God (e.g. dignity of a religious office, grace).

Attributed dignity is not inalienable and there are innumerable degrees of attributed dignity according to the respective talents, roles, functions etc. it is based on. Not only can it vary within a society, but also between societies, which might attribute different amounts of social dignity to persons such as judges or teachers, for example.

Sometimes, two of the three categories mentioned above, namely inflorescent and bestowed/attributed dignity, are subsumed under the category contingent dignity. Following this logic, Wildfeuer ${ }^{86}$ only distinguishes between intrinsic and contingent dignity. Seifert 87 , on the other hand, does not reduce but expand the scheme introduced above and distinguishes four kinds or roots of human dignity: inherent/ontological dignity, dignity of actual rational consciousness, acquired dignity and bestowed/attributed dignity. There are thus at least three classification systems, which see the dignity of human beings as either two-, three- or four-dimensional. Although these approaches of categorisation seem to be contradictory, since they imply different numbers of categories of human rights, I nevertheless suggest looking at them as complementary. Sulmasy's three-dimensional approach explicates the two-dimensional approach and Seifert's four-dimensional system explicates both the two-dimensional and threedimensional approaches. ${ }^{88}$ Combining these findings, the concept of human dignity can be graphically depicted as follows (cf. Figure 2):

85 Sulmasy (n 79) 473.

86 Armin G. Wildfeuer, 'Menschenwürde - Leerformel oder unverzichtbarer Gedanke?' in Manfred Nicht, Armin G. Wildfeuer (eds), Person - Menschenwürde - Menschenrechte im Disput (LIT Verlag, Münster, Hamburg, London 2002) 31.

87 Josef Seifert, 'Die vierfache Quelle der Menschenwürde als Fundament der Menschenrechte' in Burkhardt Ziemske, Theo Langheid, Heinrich Wilms, Görg Haverkate (eds), Staatsphilosophie und Rechtspolitik. Festschrift für Martin Kriele zum 65. Geburtstag (C. H. Beck'sche Verlagsbuchhandlung, München 1997). Josef Seifert, 'Dimensionen und Quellen der Menschenwürde' in Walter Schweidler, Herbert A. Neumann, Eugen Brysch (eds), Menschenleben - Menschenwürde. Interdisziplinäres Symposium zur Bioethik (LIT Verlag, Hamburg, München, London 2003).

88 There are almost as many classifications of sources and aspects of dignity as there are philosophers dealing with this topic. Although virtually all of them share a category, which has to do with intrinsic dignity, almost all of them understand inherent dignity as actualised, which is contrary to what Sulmasy or Seifert have in mind. So, despite sharing the same terminology, the content of the terms they use sometimes changes. Therefore, one has to exert special caution when comparing different approaches with regard to a classification of buman dignity. 


\section{The Dignity of Human Beings}

\section{Inherent/intrinsic/ ontological Dignity}

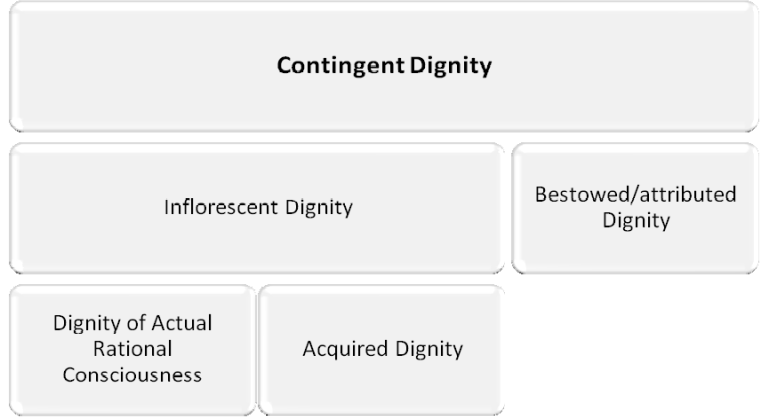

Figure 2: The Dignity of Human Beings - A Classification Scheme

When speaking about the dignity of human beings, we can, therefore, speak of inherent, inflorescent as well as attributed/bestowed dignity, whereby the aspect of inflorescent dignity can be subdivided into dignity of actual rational consciousness and acquired dignity.

\section{Observantia-Respect: The Mediator between Dignity and Human Rights}

Any complete account of human rights must consist of and be responsive to all four dimensions of the dignity of human beings. But how can the dignity of human beings actually ground human rights? How do we get from statements about dignity to the ascription of human rights? We have heard that dignity is essentially a non-neutral, positive and exalted value that indicates positive importance. As such, it asks us to respond to it adequately:

Whether one chooses or rejects something which is agreeable, but is indifferent from the point of view of value, depends upon one's own pleasure. Whether one does or does not eat an excellent meal is up to oneself. But the positive value calls for an affirmation, and the negative value for a refusal on our part. Confronted with these, the way in which one should behave is not left to one's arbitrary pleasure; instead it should be the subject of preoccupation and the right response should be given, for interest in and adequate responses on our part are due to values. ${ }^{89}$

Our response to the value of human dignity is not left to our arbitrary pleasure, but exerts a sublime demand and duty on us, namely to accord some valuing form of moral recognition to its bearer. The moral recognition required to be accorded to the bearers of dignity is respect: as has been said above, dignity is something deserving of respect.

89 Dietrich von Hildebrand, Fundamental Moral Attitudes, translated from German by Alice von Hildebrand (Longmans, Green and Co., New York 1950) chanter I. 
The dignity of human beings demands and warrants respect from others or to be more precise, the dignity of human beings is that by which human beings exact or demand respect from one another. Therefore, the key to bridging the dignity of human beings and human rights is respect. There is a value represented in human beings that entitles them to respect and that must be respected; this value is the four-dimensional dignity of human beings. If we have a close look at the relationship between the dignity of human beings and human rights, we can state that the dignity of human beings does not directly give rise to human rights. Rather, it is respect for the dignity of human beings, which does the trick. Respect, therefore, is the mediating factor between the dignity of human beings and their human rights. Human rights are the moral rights, which human beings have because they are entitled to have their dignity respected by others (who in turn have the duty to take their hats off to, i.e. respect, the dignity of other human beings). Human rights are, therefore, derivative of this basic human right. However, as long as we do not know what to understand by respect, we do not know how the dignity of human beings can ground human rights and what respect for the dignity of human beings can actually demand from us.

Respect (stemming from the Latin verb 'respicere', which can be translated with 'to look (back) at', but also 'to regard' or 'to consider') is not only an attitude or feeling (such as esteem or deference), but much more a behaviour, which is expressed by a proper regard for or recognition of something, i.e. which is expressed in and by action. Feinberg 90 has identified three distinct aspects, which have been associated with the term 'respect':

- Firstly, there is the 'Respekt' aspect of respect, which Feinberg defines as an 'uneasy and watchful attitude that has 'the element of fear' in it'91. As Dil$l^{10{ }^{92}}$ points out, 'its objects are dangerous things or things with power over the subject'. Examples of 'Respekt' are the respect a surfer has for a 25-metre high wave or the attitude one has towards everything dangerous that one has to deal with in general. 'Respekt' is not to be mistaken for fear (which might be a result of it); it is rather the awareness of the graveness of an action or situation and might be said to lift our attention.

- The second aspect of respect according to Feinberg is 'observantia', which involves regarding an object or being of value 'as making a rightful claim on our conduct, as deserving moral consideration in its own right' 93 . Observantia is respect in a practical sense, which guides our actions and requires us to behave in a certain kind of way.

90 Joel Feinberg, 'Some Conjectures on the Concept of Respect' (1973) 4 Journal of Social Philosophy 1.

91 Feinberg (n 90) 1.

92 Robin S. Dillon, 'Respect' in The Stanford Encyclopedia of Philosophy, 14 December 2009 plato.stanford.edu/entries/respect accessed 3 August 2011.

93 Dillon (n 92). 
- 'Reverentia', the third aspect of respect, is 'the special feeling of profound awe and respect we have in the presence of something extraordinary or sublime, a feeling that both humbles and uplifts us' ${ }^{94}$. Reverentia is a distinctive positive feeling of deference that one has in the presence of something he considers having exalted value.

If we think about Feinberg's three aspects of respect, we will soon see that reverentia and 'Respekt' are two sides of the same coin: both are feelings of respect, the former positive and uplifting, the latter rather negative and associated with fear. Observantia, on the other hand, is more than a feeling: it is motivating and calls for meaningful behaviour. So, when we say that the dignity of human beings necessitates or demands respect, we can only mean that it demands observantia, i.e. that it has to be respected by certain forms of behaviour, because it cannot be demanded of us to feel reverentia or 'Respekt'. There can be no demand to experience a feeling, but there can be a demand to behave in a certain way - even if such behaviour would be contrary to our feelings. When thinking about respect for the dignity of human beings, we have to bear in mind that what we are thinking about is observantia-respect.

Their dignity entitles human beings to demand observantia-respect from all other human beings. But the observantia-respect, which can be demanded on the basis of the dignity of human beings, is not the right to equal concern and respect. Rather, it is the right to individual respect according to the dignity of the human being in question; it is the right to be given what is due to one because of one's dignity - if one lacks the second, third or/and fourth dimension of human dignity, one cannot expect observantiarespect for what is not there. There is a common equal basis of observantia-respect, which can be demanded by every human being, but beyond which the observantiarespect that can be demanded differs from human being to human being. Given this foundational right of respect, human beings can never be without rights. Having said this, human beings are in a position to make a claim on the conduct and behaviour of others towards them. What does and can the duty to observantia-respect the dignity of human beings comprise? Basically, to observantia-respect the dignity of another human being requires others to turn toward it and to behave affirmatively, i.e. to give it appropriate consideration and recognition by deliberating about one's behaviour. It thus involves the duty to appropriately weigh the respective human being's value in one's deliberations about how to behave and then to behave accordingly. Therefore, the basic right the dignity of human beings grants the respective human beings is to have their dignity respected. The mere fact that a human being possesses such exalted value entitles him to having his dignity observantia-respected by others and obliges others to observantia-respect his dignity. 


\section{What Forms of Human Rights are there?}

Where does this leave us? As has been established in the previous chapter, the fact that human beings possess dignity gives them the human right to have their dignity observantia-respected. This finding, however, begs the question of the nature of this human right. What kind of moral right is the human right to have one's dignity respected? As a special class of moral rights, a human right can come in one or more of the following forms:

1. Passive right: Moral claim-right/duty

a. Moral negative claim-right in rem

A moral claim-right not to be interfered with or dealt with or treated in a certain way with the corresponding duty resting with everybody

b. Moral negative claim-right in personam

A moral claim-right not to be interfered with or dealt with or treated in a certain way with the corresponding duty resting with a specifically identified person or group

2. Active right: Moral liberty-right

a. Moral liberty-right in rem

A moral no-duty with the corresponding no-claim-right resting with everybody

b. Moral liberty-right in personam

A moral no-duty with the corresponding no-claim-right resting with a specifi cally identified person or group

3. Moral cluster-right

A combination of one or more of the above-mentioned moral claim-rights and moral liberty-rights

The first question we could try to answer is whether the human right to have one's dignity observantia-respected is a passive or an active right. The answer is rather simple: if observantia-respecting something requires us to behave in a certain way and if dignity grants its possessor the right to observantia-respect, then such a right is not a right, which is concerned with what the possessor of the dignity which is to be observantia-respected is allowed to do; rather, it is concerned with the action and behaviour of others. Consequently, it is a passive right, which obliges others. However, the human right to observantia-respect cannot be a liberty-right, i.e. a right to take a certain action or behave in a certain way. One the one hand, it does not make sense to speak of a moral liberty-right to have one's dignity respected. An active right is a right to do something; having one's dignity respected, however, does not exactly amount to doing something, but the opposite. On the other hand, if we interpret the human right to respect as an active moral liberty-right, one would have a liberty-right to respect the dignity of others - which would mean nothing else than saying that one is free from the duty to respect the dignity of others. However, such a statement would be contrary to the idea of dignity. Observantia-respect for dignity can be demanded, it is everybody's duty to observantia-respect the dignity of others. Therefore, no one is free to observantia-respect the dignity of others, since everybody is obliged to do so. Consequently, no one has an active moral liberty-right to respect. While it is true that one is free to do 
what one does not have a duty not to do, we are just not free when it comes to observantia-respecting the dignity of others.

This means that the dignity of human beings (or to be more precise: observantiarespect for the dignity of human beings) can only ground passive negative human rights or a human cluster-right:

1. Passive right: Moral claim-right/duty

a. Moral negative claim-right in rem

A moral claim-right not to be interfered with or dealt with or treated in a cer tain way with the corresponding duty resting with everybody

b. Moral negative claim-right in personam

A moral claim-right not to be interfered with or dealt with or treated in a cer tain way with the corresponding duty resting with a specifically identified per son or group

\section{Moral cluster-right}

But we can go a step further: cluster-rights have been introduced as a combination of two or more of the four basic Hohfeldian incidents of rights. Cluster- or molecular rights, therefore, are a combination of claim-rights, liberty-rights, immunity-rights and power-rights. Since we have excluded the latter two Hohfeldian instances from our discussion of moral and human rights, moral molecular rights can only be a combination of moral claim-rights and moral liberty-rights, since these are the only remaining pure Hohfeldian forms of moral rights. However, if we look at the list just presented, we will see that such a combination is no longer possible. If observantia-respect for the dignity of human beings can only ground moral and human claim-rights, it does not make sense to maintain the class of moral cluster-rights. The latter can thus also be eliminated from our list. The final list of human and moral rights, which can be derived from the dignity of human beings comprises only two items and looks as follows:

1. Passive right: Moral claim-right/duty

a. Moral negative claim-right in rem

A moral claim-right not to be interfered with or dealt with or treated in a cer tain way with the corresponding duty resting with everybody

b. Moral negative claim-right in personam

A moral claim-right not to be interfered with or dealt with or treated in a cer tain way with the corresponding duty resting with a specifically identified per son or group

By a process of philosophical deliberation and elimination, our initial list of seven conceptually possible classes of moral rights has been narrowed down to two classes. Observantia-respect for the four dimensions of the dignity of human beings can ground the following forms of human rights (cf. Figure 3): 




Respect for ...

\section{Figure 3: Forms of Human Rights Arising from Respect for the Dignity of Human Beings}

Proposing that human rights can only come as a passive negative moral right in rem and/or in personam, however, is not to say that our originally established list of seven classes of moral rights is wrong. It is only to say that grounding human rights in human dignity limits the actual number of possible classes to two. If one takes the dignity of human beings to be the justification for human rights, one has to dispel the idea that any of the four dimensions of dignity can ground every moral right and content oneself with the fact that such a justification can only be used to ground passive negative moral rights. In short, if there is such a thing as a human right to health justified by reference to the dignity of human beings, this right can only be a passive and negative claim-right in rem or in personam.

\section{Human Rights: Strict versus Non-Strict}

However, virtually no philosopher, politician and contemporary thinker applies the term 'human rights' in the way I suggest. Rather, they use it in a more strict sense to imply those moral rights of human beings to which all human beings are entitled, i.e. which are equal, inalienable and universal. Understood like this, human rights constitute the minimal standard of and for human behaviour, i.e. the least every human being can demand. Human rights are "concerned with avoiding the terrible rather than with achieving the best' 95 . They aim at protecting minimally good lives for all human beings and are thus about the 'lower limits on tolerable human conduct'96, rather than 'great aspirations and exalted ideals, saintly restraint and heroic fortitude and awesome beauties that enrich life'97. As such minimal standards, they furthermore leave room for cultural and institutional accommodation and peculiarities. In order to align this article's understanding of human rights with the common one, we have to introduce the distinction between human rights in a strict or narrow sense and human rights in a non-

95 James W. Nickel, 'Human Rights' in The Stanford Encyclopedia of Philosophy, 29 July 2006 plato.stanford.edu/entries/rights-human accessed 3 August 2011.

96 Henry Shue, Basic rights: subsistence, affluence, and U.S. foreign policy $\left(2^{\text {nd }}\right.$ edn Princeton University Press, Princeton 1996) xi.

97 Shue (n 96) xi. 
strict or broader sense. In a non-strict sense, human rights are those moral rights, which can only be possessed by human beings, which are grounded in the dignity of human beings, but which do not necessarily have to be possessed by all human beings of all times. In contrast and as has been adumbrated, human rights in a strict sense are those moral rights, which can only be possessed by human beings, which are grounded in the dignity of human beings and which are possessed by all human beings of all times equally, inalienably and universally. As the account of human rights introduced in this article has been justified by reference to the status theory, which takes the dignity of human beings as the property, that makes it fitting to ascribe certain moral rights to human beings, we have to render the distinction introduced above more precisely. The dignity of human beings can be divided into contingent dignity as well as inherent or intrinsic dignity. Whereas the latter dimension of dignity is universal and inalienable, the former dimension (which comprises the three dimensions 'dignity of actual rational consciousness', 'acquired dignity' and 'bestowed dignity') depends on capabilities, properties or behaviours, which some human beings might have or exhibit while others might not. Human rights in their strict sense can, therefore, only arise from observantiarespect for the inherent, i.e. ontological dignity of all human beings. Consequently, contingent dignity is the foundation for human rights in their non-strict sense. Summing up these findings, we can draw up the following tree of moral and human rights (cf. Figure 4):



Figure 4: The Classification of Moral Rights

This has certain implications for what has been established so far. Over the course of the preceding pages, it was argued that there are no moral positive claim-rights and 
that observantia-respect for the dignity of human beings can only ground passive negative claim-rights in rem and/or personam. Consequently, the initial list of seven possible forms of moral rights was reduced to two moral rights, which can serve as human rights grounded in dignity. This chapter, on the other hand, argued that we have to narrow our understanding of human rights to its strict sense, i.e. that sense, which sees human rights as inalienable, universal and equally held by all human beings. Understood like this, such human rights can only be justified with reference to the ontological dignity of human beings, since the other dimensions of dignity do not exhibit universality or inalienability (cf. Figure 5).

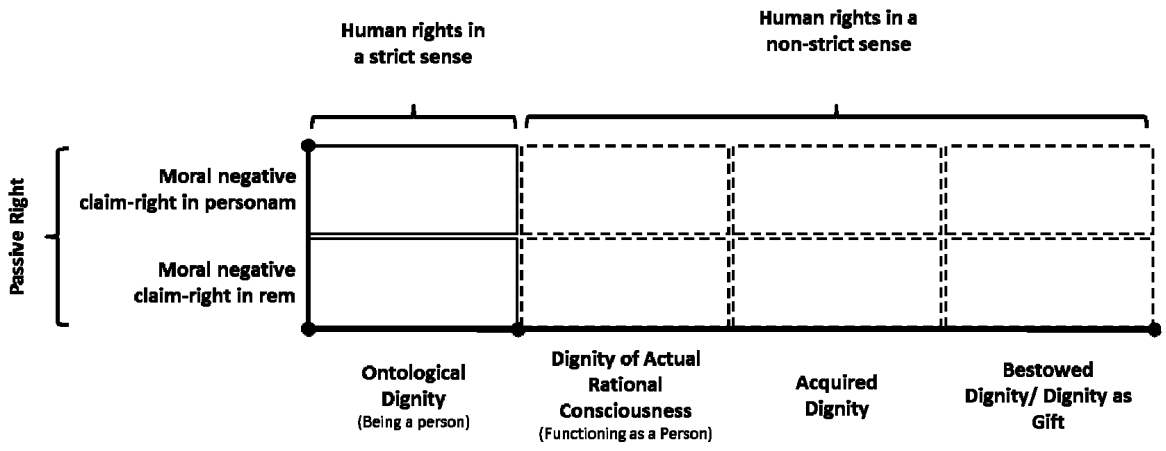

Respect for ...

\section{Figure 5: Human Rights in a Strict Sense and the Dignity of Human Beings}

What does this mean for the argument of this article? Well, it simply means that if we want there to be such a thing as an unalienable, inherent and universal human right, such right can only be a passive negative claim-right grounded in the ontological dignity of human beings.

\section{Concluding Remarks}

The preceding pages have been devoted to developing a philosophical foundation to the concept of human rights, a theory of human rights. This theory is based on the insight that when it comes to human rights, we know that human rights are rights. But they are not just any rights. They are neither positive nor pre-positive conventional rights, but pre-positive pre-conventional and thus moral rights. However, they are also not just any moral rights. They are a special class of moral rights, namely the moral rights of human beings which are grounded in the dignity of human beings. The dignity of human beings makes it fitting to ascribe certain moral rights to them and respectful treatment of these rights appropriate. Human rights are and must be validated by reference to the dignity of human beings. Therefore, human rights have three characteristics: they are moral rights, they are the moral rights of human beings and they are those 
moral rights of human beings, which are validated by reference to the dignity of human beings.

The dignity of human beings refers to a property or properties by which man is considered worthy, honourable or estimable and which lifts man out of neutrality - both with respect to the rest of creation as well as to his fellow men. Man is and can be lifted out of neutrality by four forms of dignity:

- Ontological dignity (being a person)

- Inflorescent dignity

- Dignity of actual rational consciousness (functioning as a person)

- Acquired dignity

- $\quad$ Bestowed dignity/Dignity as gift

As an exalted value, the dignity of human beings exerts a sublime demand and entitles their possessors, i.e. gives them the moral and human right, to have their dignity observantia-respected. This is how the dignity of human beings grounds human rights: qua possessing dignity, human beings have the human right to have their dignity observantia-respected. Doing so requires other human beings to behave affirmatively, i.e. to give appropriate consideration and recognition in deliberating about their behaviour. It involves the duty to weigh the respective human being's value appropriately in deliberations about how to behave and to behave accordingly.

According to this account of human dignity, one can distinguish between human rights in a strict sense and human rights in a non-strict sense. Human rights in a strict sense are only those moral rights of human beings, which are universal and inalienable; in a non-strict sense they are those human rights, which are not necessarily equally held by all human beings and which can be lost. Consequently, only ontological dignity but not the other three dimensions of dignity (contingent dignity) - can be used to justify human rights understood in a strict sense. When speaking of human rights in a strict sense one can only mean passive negative rights justified with reference to ontological dignity.

I have tried to present not only elements of a human rights theory, but a consistent account of what makes a right a human right and how. The theory of human rights presented above takes an important premise underlying international law seriously, namely that human rights are something inherent to human beings and grounded in dignity. If we subscribe to these premises, the human rights mentioned in international law can only be human rights in a strict sense and can, therefore, only be grounded in the ontological dignity of human beings, i.e. their personhood. A human right must not a fancy brand which is meant to give some right special moral importance but should rather be treated as a concept with philosophical rigour. The theory outlined above is a helpful instrument in doing so and is capable of overcoming the problems caused by the regrettable lack of human rights theory. Hopefully, it can be of use in and enrich the human rights discourse and practice. 